\title{
Higher education in Turkey: Subsidizing the rich or the poor?
}

\author{
Asena Caner ${ }^{\mathrm{a}, 1}$, Cagla Okten ${ }^{\mathrm{b}, 2, *}$

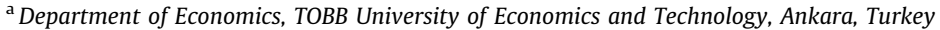 \\ ${ }^{\mathrm{b}}$ Department of Economics, Bilkent University, Ankara, Turkey
}

\section{A R T I C L E I N F O}

\section{Article history:}

Received 2 March 2012

Received in revised form 18 March 2013

Accepted 30 March 2013

\section{JEL classification:}

I21

I 22

I24

015

\section{Keywords:}

Higher education

Public finance of higher education

Turkey

\begin{abstract}
A B S T R A C T
We investigate how the benefits of publicly financed higher education in Turkey are distributed among students with different socioeconomic backgrounds. We use a dataset from a nationally representative sample of university entrance exam takers together with data on government subsidies to public universities. We compare the characteristics of students who succeed in the exam to those who do not and those who enter public universities to those who go to private ones. Our econometric analyses based on a threestage selection model reveal that students from wealthier and more educated families are more likely to be successful at university entrance. Unlike the findings in other countries, students who enroll in private universities come from higher income and more educated families. Among those who enter public universities, students from higher income and better educated families are more likely to go to universities that receive larger subsidies from the government.
\end{abstract}

(c) 2013 Elsevier Ltd. All rights reserved.

\section{Introduction}

In many countries, governments heavily subsidize higher education. There are two main economic arguments in favor of this policy. First, in the absence of government involvement, borrowing against future human capital is very limited and in particular, students from low income families are likely to find it difficult to afford college even when their private returns to higher education are greater than their costs. Second, social returns to higher education are likely to be higher than private returns and hence in a free market the level of higher education is likely to be less than the socially optimal amount. However, if government is subsidizing higher education of students from high income families who would have gone to college in the

\footnotetext{
* Corresponding author. Tel.: +90 312290 2225; fax: +90 3122665140 . E-mail addresses: acaner@etu.edu.tr (A. Caner), cokten@bilkent.edu.tr (C. Okten).

${ }^{1}$ Tel.: +90 312292 4111; fax: +90 3122924104 .

2 IZA Research Fellow.
}

absence of government subsidies, then these subsidies may not be justified with either of these arguments and may simply result in an income transfer from the poor to the rich.

In this paper, we empirically examine the characteristics of the beneficiaries of public expenditure on higher education using a nationally representative survey of university entrance exam applicants from Turkey, merged with data on government subsidies to public universities. We ask how the subsidy per student varies across students with different backgrounds and whether public and private university students are different in terms of family characteristics. We also compare applicants who are placed at a program to those who are not.

In Turkey, most university students attend public universities and public universities are heavily subsidized. Households with students in public universities receive inkind benefits in the form of tuition free education. We assume that the amount of spending on a public university determines the quantity of resources that its students have access to, eventually leading to better outcomes in school life and in the labor market. Therefore, it is essential to 
know which types of families and students are supported by public funds.

There are only a few studies that empirically examine the characteristics of the beneficiaries of public expenditure on higher education. Rozada and Menendez (2002) analyze the socioeconomic characteristics of individuals attending and not attending university in the Buenos Aires metropolitan area and find that no socioeconomic variables are statistically significant in determining public university attendance. Liu, Chou, and Liu (2006) examine the characteristics of the beneficiaries of public expenditure on higher education in years 1996-1999 in Taiwan, where subsidies for higher education generally come in the form of government-financed low tuition public universities. Liu et al. (2006) advance the approach in Rozada and Menendez (2002) by using a two part model to estimate the conditional probabilities of entering a public university and entering one of the three types of public universities. They find that public university students tend to come from wealthier families compared to students of private universities, and that students attending the top five public universities come from wealthier families than those attending lower tier public universities which on average receive lower government subsidies than the top five.

In this paper we contribute to this small literature in several dimensions. First, we use data from a nationally representative survey of university entrance exam applicants from Turkey where the private higher education sector is not subject to price regulation. In Taiwan, where the only other national study is from, the ministry of education set uniform standards for tuition fees charged by private colleges until 1999 (Taipei Times, 2000). A cap on prices may adversely affect the quality of private institutions, and thereby reduce demand for these institutions. By contrast, in Turkey, there are high quality private universities that attract students with high socio-economic status.

Second, we observe in our data the amount of per student subsidy not only at a national or university level, but separately for universities and for schools within universities. Previous studies estimate per student subsidy very roughly and only at the national level (by dividing the total higher education expenses by the total number of students) or by the type of the higher education institution (universities versus technological institutes, as in Antoninis and Tsakloglou (2001)). Such an approach, by assigning an average amount to all students, evens out the variation across universities and schools when in fact subsidies received by students at the same university may be very different.

Third, our method allows us to examine the determinants of the students' decisions at each stage separately. We estimate a three-stage Heckman model where the first stage is success in the exam, the second stage is public versus private university choice, and the third stage is the allocation of students to public universities. We supplement our findings with a three-part model which can be used to derive the marginal effects of socio-economic characteristics on the educational subsidy received from the government by an average exam taker in Turkey. Since we use the implicit per student subsidy in a program-university pair as our measure, our categorization of public universities is more precise than in Liu et al. (2006) who divide public universities into three groups.

We find that students entering public universities come from lower income families than students entering private universities. This is a strikingly contrary result to Liu et al. (2006) and can be attributed to the lack of price controls in the private higher education sector in Turkey. This result has important policy implications. A private higher education sector that is not subject to price controls can provide a high quality product that attracts wealthier students in a country where public provision has traditionally been the norm. Sorting of high income students into private universities and low income students into public universities results in a higher education system where government subsidizes higher education of low income students who may not have gone to college due to borrowing constraints.

Among those entering public universities, students who come from higher income and better educated families tend to enter public universities that receive higher government subsidies. There is tough competition to enter the better funded public universities. Students spend substantial amounts on private tutoring in order to get into the better programs/universities. Tansel and Bircan (2006) report that private tutoring centers are expensive and usually beyond the reach of a household with average income. In our survey data we find that total private tutoring expenditures spent during three years of high school as a fraction of yearly income is about 7 percent. We also find that students from wealthier families spend more on private tutoring and are also able to get into universities that receive higher government subsidies.

The plan of our paper is as follows: in the next section, we discuss the related literature. Section 3 presents the setting for the university entrance exam and the government financed higher education system in Turkey. Section 4 , presents the data and the descriptive statistics. Section 5 provides the econometric framework. In Section 6, we present and discuss our results. In Section 7, we discuss the policy implications of our analysis; Section 8 concludes.

\section{Background}

There is a sizable literature on the public finance of higher education and its distributional consequences. It has been argued that subsidies to higher education have a regressive distributional effect. Given that wealthier families enroll more children in higher education, there may be an unwanted "perverse" distributional impact of these subsidies to higher education (Friedman, 1962, p. 105).

Public finance of education can be modeled as a publicly provided private good, financed by a proportional income tax (see, for instance, the public economics textbook by Atkinson and Stiglitz (1980)). There are implications of such a model on both the resources devoted to education and on income redistribution implicit in the financing scheme. In such a model, if income distribution is skewed so that the mean income is greater than the median income, if there is proportional taxation and if collective choice on whether education should be financed publicly 
or privately is determined by majority voting, then the majority chooses education to be financed publicly. Consequently, resources are transferred from higherincome to lower-income individuals.

However, as shown by a branch of the political economy literature that evolved from the Fernandez and Rogerson (1995) study, the opposite result is possible. If education is costly, if households are credit constrained and they vote over the extent to which education is subsidized, higher income individuals choose to subsidize the cost of education only partially. This effectively excludes poorer individuals from receiving this education and simultaneously extracts resources from them.

An early and very commonly cited empirical study shows that in California worse-off households benefit less from higher education subsidies than better-off households do, even after taking into account their lower tax payments (Hansen \& Weisbrod, 1969). The study was criticized on the grounds that the analysis does not compare the benefits and payments of different income groups as it should do, but it compares only families with children to childless families. Public higher education system in California was actually found to be progressive when the analysis was based on different income groups (Pechman, 1970).

A number of other studies contributed to this debate. In Canada (Crean, 1975), in Japan (James \& Benjamin, 1987) and in Germany (Barbaro, 2005), the public finance of higher education is found to be progressive. The system is found to be regressive in Kenya ("... a select few receive a very large payoff ..." (Fields, 1975, p. 257)), in Quebec (Lemelin, 1992) and in Greece (Antoninis \& Tsakloglou, 2001). In Greece, the children of the richest segments of the population are reported to be significantly over-represented in the schools with the highest cost per student, such as medicine and engineering.

Some authors stated that the analysis should focus on lifetime income distribution within cohorts instead of on current income distribution within the population (Crean, 1975; James \& Benjamin, 1987). Parents of university-age children are usually in their late thirties to mid-fifties, and therefore in an advanced stage of their earnings profile. For this reason, they will appear in the cross-section as high earners. When the extent of progressivity is estimated by considering whether these families are subsidized by other families in the cross section, the result is to overestimate the regressivity of subsidies. However, redistribution from those who never benefit from the program to those who do and redistribution that takes place between families who at some time or another send their children to higher education are two different concepts that should not be confused. The latter shifting should not be regarded as redistribution. In our study, we have the opportunity to observe the family backgrounds of a nationally representative sample of all exam takers, i.e. all university age children who apply for a place at a university. Within this group we compare the background variables of those who entered a university to those who did not, therefore our study is not subject to such bias.

Our study is related also to the equality of opportunity literature. As Roemer (1998) suggests, equality of opportunity is realized when the circumstances that are beyond the control of an individual (such as the family, the neighborhood, the genes) but that affect the achievements in life do not matter for the determination of the achievements. This means that the playing field should be leveled before the game begins. Ferreira, Gignoux, and Aran (2010) use the educational attainment of parents and the number of siblings a person grew up with as indicators, among others, of circumstances in Turkey. In our study, we include these two variables in our set of controls to investigate how circumstances influence students' exam performance and the amount of subsidy they receive.

Most similar to our study are the Rozada and Menendez (2002) and Liu et al. (2006) studies. The former finds that in Argentina, individuals attending the university are in the top deciles of the income distribution and come from relatively highly educated families. Moreover, there is little difference in terms of socioeconomic variables between those attending tuition-free public institutions and those attending private colleges, which implies that there is an implicit transfer to the richest individuals in society. As poor students in Argentina are excluded from higher education, tuition-free education at public universities does not benefit them. The latter study is on Taiwan where students take a nationwide university entrance examination, as in Turkey, and are assigned to major in a particular field and university based on their score. The authors find that, consistent with the former study, family background variables such as family income and parental education have an important impact on the educational achievements of children and that government spending on higher education actually subsidizes richer families.

We know that in many developing countries demand for higher education exceeds supply by a considerable margin and the excess demand is satisfied by the private provision of higher education. There are studies that report that public universities are better and more prestigious than the private ones and that members of richer households have a substantially higher probability to enter the public institutions (for example in Greece, Antoninis \& Tsakloglou, 2001; in Taiwan, Liu et al., 2006). The policy proposal to enhance the distributional performance of higher education system in such a situation is to introduce tuition charges combined with a selective scholarship scheme (see for example, Antoninis \& Tsakloglou, 2001; Psacharopoulos, Tan, \& Jimenez, 1986; Rozada \& Menendez, 2002).

\section{The setting}

\subsection{The university entrance exam in Turkey}

Students need to take a highly competitive nationwide test (called OSS during the period of study), in order to be enrolled in a university in Turkey. This test is given once a year and more than one million students participate each year. In 2002, the year that our data was collected, the exam was composed of verbal, quantitative and foreign language sections. Students decided which sections to answer based on their major choices. The raw OSS score was a weighted average of the scores on these sections, with a small adjustment for high school performance. In 
Turkey, high school students choose a field of study. In the 2002 data provided by the Student Selection and Placement Center (OSYM), there were four fields; Science, Turkish-Math (TM), Social Sciences and Foreign Languages. Students were given extra points if their major choices were compatible with their fields.

Once the OSS scores were available, students who scored above a certain threshold were asked to submit their choice lists. Each candidate could include up to 24 choices (program-university pairs) in the list, ranked from the most preferred to the least preferred. The students were ranked by their OSS scores. The candidates with the highest scores were admitted to their top choices. As the quotas of the programs preferred by the candidates with the highest scores were filled, candidates with lower OSS scores were assigned to their less preferred programs, or to no programs at all if the quota of all the programs in their choice lists had already been filled. Therefore, assignment to a program-university pair was a function of both the OSS score and the choice list of a candidate. Knowing his own score and the minimum acceptance scores of programs in the previous year, a student could have some rough idea about the feasible set of program-university pairs.

\subsection{Government financing of higher education}

In Turkey, higher education is largely subsidized by the government. In the 2003-2004 academic year, 68,697 students enrolled in private universities were about $5.7 \%$ of university students (YOK, 2004, p. 46). In 2005, the share of private university students was still small at about 9.3\% (YOK, 2007a, 2007b). In 2005, the 53 public universities were located in many different cities, but the 24 private universities were located only in Istanbul, Ankara and Izmir, the largest cities in the country.

Table 1 presents the sources of revenue for Turkish public universities, in years 2000-2005. The main source of revenue is government subsidies, with a share that ranges from 52 to 57 percent of the total. The second source is the funds generated by the universities themselves, which include revolving funds revenues (from the provision of health services by university hospitals, consulting or educational services by professors) and the revenues of cafeterias, parking lots, dormitories, etc. owned by the universities. Student fees are the third and the smallest source of revenue, amounting to only 4-5 percent of total revenue.

Table 1

Sources of revenue in public universities (\% in total).

\begin{tabular}{llll}
\hline Year & $\begin{array}{l}\text { Government } \\
\text { subsidies }\end{array}$ & $\begin{array}{l}\text { Funds generated } \\
\text { by the universities }\end{array}$ & Student fees \\
\hline 2000 & 57 & 38 & 5 \\
2001 & 52 & 44 & 4 \\
2002 & 52 & 44 & 4 \\
2003 & 57 & 39 & 4 \\
2004 & 56 & 40 & 5 \\
2005 & 57 & 38 & 4 \\
\hline
\end{tabular}

Source: YOK (2005), Table 8.16.

Note: The percentages may not always add up to 100 due to rounding.

\section{The data}

\subsection{The university entrance exam data}

The university entrance exam data that we use includes both the applicants' and their families' characteristics. This valuable dataset from year 2002 combines the information from the students' application documents with the information collected from a survey administered at the time of their applications. The dataset was provided by the OSYM of Turkey and it contains one random sample from each of the four high-school fields; Science, TurkishMath (TM), Social Sciences and Foreign Languages. Each sample contains data on about $30,000-40,000$ students. $^{3}$ We pool the four samples and hence use the data from all four high-school fields. In the OSS data, for each student we have his OSS scores, the student's choice list which includes the codes of program-university pairs that the student ranks in his list, whether the student entered university and if so, the program-university pair that he was admitted to. In 2002, there were about a hundred different four year degree programs.

Our dataset also includes information on family and individual characteristics such as the gender of the student, the number of children in the family, education of the parents, employment and social security status of the parents, family income (in terms of income brackets), expenditures on private tutoring to prepare for the exam, the number of times that the student has taken the exam and population of the area that student attended high school. The data on the socio-economic background of the students were collected via a survey of the students registering to take the OSS.

The descriptive statistics of the data used in the econometric analysis are reported in Table 2a. The dummy variables for parental education are illiterate, literate, primary school graduate ( 5 years of schooling), junior high school graduate (8 years of schooling), high school graduate (11 years of schooling), junior college graduate (2 years of vocational college), college graduate (4-6 years of college) and master's or Ph.D. degree, respectively. The other variables shown in Table 3 are the logarithm of family income, ${ }^{4}$ male dummy, the number of children in the family, the student's high school field, a dummy variable for whether the father is affiliated with the public sector, the number of times the student has taken the exam ( 1 if it is the first time, 2 if it is the second time and so on), and the logarithm of the population of the area in which the student went to high school.

In the first part of the table we show the statistics for the entire sample and in the second and third parts the statistics for those who were successful in the exam and who were not. It seems that successful students come from bigger cities and have families with higher income, fewer children and better educated parents. Repeat-taking is

\footnotetext{
${ }^{3}$ The raw number of observations in science, foreign language, TM and social science fields are 29,000,37,000,39,000 and 39,000, respectively.

4 In January 2005, 6 zeros were omitted from the Turkish currency unit. We express 2002 monetary values without the 6 zeros.
} 
Table 2a

Descriptive statistics (student characteristics, means and standard deviations).

\begin{tabular}{|c|c|c|c|c|c|c|c|c|c|c|c|}
\hline \multirow[t]{2}{*}{$\begin{array}{l}\text { Type of } \\
\text { variables }\end{array}$} & \multirow[t]{2}{*}{ Variables } & \multicolumn{2}{|c|}{$\begin{array}{l}\text { All }(N=93,266)\end{array}$} & \multicolumn{2}{|c|}{$\begin{array}{l}(2) \\
\text { Success }=1 \\
(N=18,464) \\
\text { Placed at a } \\
\text { university }\end{array}$} & \multicolumn{2}{|c|}{$\begin{array}{l}(3) \\
\text { Success }=0 \\
(N=74,802) \\
\text { Not placed } \\
\text { at a university }\end{array}$} & \multicolumn{2}{|c|}{$\begin{array}{l}(4) \\
\text { Public = } 1 \\
(N=16,251) \\
\text { Placed at a } \\
\text { public university }\end{array}$} & \multicolumn{2}{|c|}{$\begin{array}{l}(5) \\
\text { Public }=0 \\
(N=2213) \\
\text { Placed at a } \\
\text { private university }\end{array}$} \\
\hline & & Mean & St. Dev. & Mean & St. Dev. & Mean & St. Dev. & Mean & St. Dev. & Mean & St. Dev. \\
\hline \multirow{3}{*}{$\begin{array}{l}\text { Family } \\
\text { resources }\end{array}$} & Logarithm of family income & 5.692 & 0.752 & 5.911 & 0.810 & 5.638 & 0.727 & 5.820 & 0.756 & 6.578 & 0.881 \\
\hline & Male & 0.508 & 0.500 & 0.476 & 0.499 & 0.516 & 0.500 & 0.473 & 0.499 & 0.503 & 0.500 \\
\hline & Number of children & 3.234 & 1.211 & 2.877 & 1.156 & 3.322 & 1.208 & 2.929 & 1.155 & 2.494 & 1.090 \\
\hline \multirow{3}{*}{$\begin{array}{l}\text { High school } \\
\text { field }\end{array}$} & Science & 0.225 & 0.418 & 0.380 & 0.485 & 0.187 & 0.390 & 0.394 & 0.489 & 0.276 & 0.447 \\
\hline & Social & 0.259 & 0.438 & 0.094 & 0.292 & 0.300 & 0.458 & 0.089 & 0.285 & 0.129 & 0.335 \\
\hline & Language & 0.237 & 0.425 & 0.314 & 0.464 & 0.218 & 0.413 & 0.310 & 0.462 & 0.345 & 0.475 \\
\hline \multirow{7}{*}{$\begin{array}{l}\text { Father's } \\
\text { education } \\
\text { variables }\end{array}$} & Literate & 0.050 & 0.218 & 0.029 & 0.168 & 0.055 & 0.229 & 0.030 & 0.171 & 0.019 & 0.138 \\
\hline & Primary school graduate & 0.396 & 0.489 & 0.294 & 0.456 & 0.421 & 0.494 & 0.311 & 0.463 & 0.170 & 0.376 \\
\hline & Junior high school graduate & 0.134 & 0.340 & 0.112 & 0.315 & 0.139 & 0.346 & 0.117 & 0.322 & 0.071 & 0.258 \\
\hline & High school graduate & 0.202 & 0.401 & 0.224 & 0.417 & 0.197 & 0.397 & 0.228 & 0.419 & 0.193 & 0.395 \\
\hline & Junior college graduate & 0.053 & 0.223 & 0.069 & 0.254 & 0.049 & 0.215 & 0.072 & 0.259 & 0.044 & 0.206 \\
\hline & College graduate & 0.124 & 0.330 & 0.230 & 0.421 & 0.098 & 0.298 & 0.205 & 0.404 & 0.414 & 0.493 \\
\hline & Master's or Ph.D. degree & 0.009 & 0.096 & 0.026 & 0.159 & 0.005 & 0.072 & 0.019 & 0.136 & 0.078 & 0.269 \\
\hline \multirow{7}{*}{$\begin{array}{l}\text { Mother's } \\
\text { education } \\
\text { variables }\end{array}$} & Literate & 0.094 & 0.292 & 0.067 & 0.250 & 0.101 & 0.301 & 0.071 & 0.257 & 0.038 & 0.190 \\
\hline & Primary school graduate & 0.465 & 0.499 & 0.394 & 0.489 & 0.483 & 0.500 & 0.417 & 0.493 & 0.230 & 0.421 \\
\hline & Junior high school graduate & 0.071 & 0.257 & 0.078 & 0.267 & 0.070 & 0.255 & 0.078 & 0.268 & 0.077 & 0.267 \\
\hline & High school graduate & 0.130 & 0.336 & 0.207 & 0.405 & 0.111 & 0.314 & 0.191 & 0.393 & 0.319 & 0.466 \\
\hline & Junior college graduate & 0.031 & 0.172 & 0.056 & 0.230 & 0.024 & 0.154 & 0.055 & 0.229 & 0.059 & 0.235 \\
\hline & College graduate & 0.040 & 0.195 & 0.092 & 0.290 & 0.027 & 0.161 & 0.077 & 0.267 & 0.203 & 0.403 \\
\hline & Master's or Ph.D. degree & 0.002 & 0.048 & 0.008 & 0.089 & 0.001 & 0.030 & 0.005 & 0.069 & 0.031 & 0.173 \\
\hline \multirow[t]{3}{*}{$\begin{array}{l}\text { Other control } \\
\text { variables }\end{array}$} & $\begin{array}{l}\text { Father works in the } \\
\text { public sector }\end{array}$ & 0.258 & 0.438 & 0.313 & 0.464 & 0.245 & 0.430 & 0.321 & 0.467 & 0.250 & 0.433 \\
\hline & Times exam taken & 1.985 & 1.170 & 1.696 & 0.949 & 2.057 & 1.208 & & & & \\
\hline & Ln population & 12.143 & 1.945 & 12.500 & 1.791 & 12.055 & 1.972 & & & & \\
\hline
\end{tabular}

Source: Authors' calculations.

very common in Turkey; an average successful student has taken the exam 1.6 times, an unsuccessful one has taken the exam about two times. There is evidence that a student's field choice in the high school may be correlated with his exam success. Although the four fields are quite evenly distributed in the whole sample, 38 percent of successful students come from the science field. The fathers of successful students are more likely to be employed in (or retired from) the public sector. ${ }^{5}$

In the fourth and fifth parts of the table, we restrict the sample to those who were successful in the exam and compare the students placed at a public university to those placed at a private university. Compared to public university students, private university students in Turkey seem to come from higher income families and have better educated parents; their fathers are less likely to be public sector employees. Students that are placed in private universities seem less likely to be in the science field and more likely to be in the social field indicating possible specialization of private universities in certain fields.

\footnotetext{
${ }^{5}$ Public sector employment is known to offer job security and stability. According to the Turkish social security system valid in 2002, a person was either covered by the public sector program (called Emekli Sandigi), covered by a private sector program (called SSK or Bag-kur), or not covered at all. The public sector social security program offers the most generous retirement and health benefits (Caner \& Okten, 2010).
}

We conduct several $t$-tests on the equality of means of two groups. The hypothesis of the equality of mean family incomes of public and private university students is rejected with a very small $p$-value $(t=43.28)$. The equality of mean family incomes of public university students and those who failed in the exam is again rejected with a very small $p$-value $(t=28.75)$. These findings hint us that private university students come from higher income families than public university students and that public university students are richer than those who failed in the exam, without controlling for any other factors.

Family income matters for success in the exam and also for the public versus private university choice. Table $2 \mathrm{~b}$ shows that in the lowest income group, $86 \%$ of students failed in the exam whereas in the top income group 66\% did. Although the share of private university students

Table 2b

The percentages of those who fail, who attend a public university, who attend a private university by income groups.

\begin{tabular}{lllc}
\hline Income groups & Success = 0 & Public = & Public = 0 \\
\hline $\begin{array}{l}\text { Lowest } 37 \% \text { of the } \\
\text { population }\end{array}$ & $86 \%$ & $13 \%$ & $1 \%$ \\
The next $40 \%$ & $82 \%$ & $17 \%$ & $1 \%$ \\
The next $13 \%$ & $77 \%$ & $20 \%$ & $3 \%$ \\
Top 10\% & $66 \%$ & $22 \%$ & $12 \%$ \\
\hline
\end{tabular}

Source: Authors' calculations. 
Table 3

Per student subsidy at some schools (TL per student, 2005 prices).

\begin{tabular}{|c|c|c|c|c|c|c|}
\hline & Mean & Median & Minimum & Maximum & Standard deviation & $N$ \\
\hline Medicine & 20,300 & 19,961 & 1702 & 10,578 & 2100 & 37 \\
\hline Dentistry, pharmacy & 8395 & 19,961 & 566 & 68,306 & 10,793 & 25 \\
\hline Faculty of arts and science & 3266 & 2464 & 1016 & 16,360 & 2531 & 65 \\
\hline Engineering, architecture & 3979 & 2939 & 1701 & 14,814 & 2527 & 71 \\
\hline Law & 3235 & 2750 & 1087 & 8586 & 1950 & 14 \\
\hline Management, economics & 2318 & 1841 & 855 & 7941 & 1403 & 59 \\
\hline Fine arts, literature, history & 3769 & 3524 & 1473 & 9172 & 1515 & 27 \\
\hline Education & 2068 & 1839 & 1120 & 6757 & 937 & 63 \\
\hline
\end{tabular}

Source: Authors' calculations based on Ministry of Finance and OSYM data.

Notes: The number of observations $(N)$ may exceed the total number of public universities in year 2005, which was 53, in cases where there are more than one school in the category within the same university. For example, if a university has both an engineering and an architecture schools, that university is counted twice in the 'Engineering, Architecture' group.

increases by income, so does the share of public university students. In the top income group, public university students outnumber private university students.

\subsection{The Ministry of Finance (MOF) data}

These data include budget realizations of expenditures of public universities in year 2005 (the closest year to 2002 for which detailed data could be obtained from the MOF). The data were utilized to estimate the per student subsidy, calculated by dividing the total recurrent expenditures of schools by the number of students enrolled in those schools.

Recurrent expenditures of a university are the expenditures that are essential for the continuation of educational activities at the university. They include: (1) Personnel expenditures; (2) Premium payments by the government to social security agencies; (3) Purchase of goods and services (includes office equipment, stationary, periodicals, utilities, small repair and maintenance, materials for laboratory experiments, travel allowances, etc.); (4) Current transfers (includes payments to retirees, treatment of students in university medical center, etc.); (5) Capital expenditures (only small repair and maintenance is included).

Important for our study, we can also see the breakdown of recurrent expenditures by institutional divisions, which can be grouped into administrative (such as the President's Office, Personnel Department) and academic divisions (schools). The administrative divisions do not have educational functions; however their existence is essential for a university to function properly. Therefore, the subsidy allocated from the national budget to a school is defined as the total recurrent expenditures of the school plus its estimated share in total administrative recurrent expenditures. Per student subsidy is this total amount divided by the number of students in the school.

An advantage of the MOF data is that we can identify the per student subsidy not only at the university level but also at the school level. This is important, since previous studies estimate per student subsidy very roughly and only at the national level (by dividing the total higher education expenses by the total number of students) and therefore overlook the variation in per student subsidy across universities and schools. We assume that students of all programs at a school (for example all engineering students at a School of Engineering) receive the same per student subsidy, since we do not have data on expenditures at the program level.

There were a total of $1,256,920$ undergraduate students (excluding open university-distance education-students) enrolled in the 53 public universities in year 2005. The average per student subsidy in our data is $2713 \mathrm{TL}$, but there is non-negligible variation in the per student subsidy by school. Table 3 shows that per student subsidy tends to be high in medical schools, in dentistry and pharmacy, while it is low in education, management and economics. Across programs, the variation in per student subsidy that arises from differences in the cost of providing education is understandable; however, there is substantial variation also across universities for the same program. For example, among the 59 management or economics programs in Turkish public universities, the minimum is $855 \mathrm{TL}$ per student while the maximum is $7941 \mathrm{TL}$. We assume that recurrent expenditures eventually affect the quantity of resources that its students have access to. The variation of per student subsidy across schools and universities is an important statistic, because it shows that some students benefit from the public education system more than others do.

In Appendix Table A1, we present the universities that are the recipients of highest per student subsidies in some randomly selected programs. Most of the universities in the table are well established and prestigious universities. According to MOF representatives, the factors that can account for the higher per student expenditures at some universities are having a larger campus, having old (sometimes historical) buildings, being located in a colder part of the country or having priority due to being in a less developed area. Our observation is that while these factors may be relevant, the universities with the highest per student expenditures tend also to be the most prestigious public universities that are very highly demanded by students.

Compared to per student expenditure made from public sources, enrollment fees charged by public universities are very small. The annual fees varied from $147 \mathrm{TL}$ to $458 \mathrm{TL}$ per student in 2005 , depending on the major of study. ${ }^{6}$ The

\footnotetext{
${ }^{6}$ Authors' calculations based on fee information from the University Entrance Exam Application Booklet, year 2005, OSYM. The average US\$/TL exchange rate in 2005 was $1 \mathrm{USD}=1.34 \mathrm{TL}$. Thus, $147 \mathrm{TL}$ and $458 \mathrm{TL}$ are about US\$ 110 and 342, respectively.
} 
highest fees were paid by students in medicine, dentistry, pharmacy and state conservatory for the arts. It is clear that students at public universities in Turkey pay only a small share of the cost of higher education, in other words they contribute very little to cost recovery. In private universities, whose main source of revenue is tuition fees, students paid as much as 26,500 TL (Turkish Liras) and as little as 4266 TL annually in $2005 .^{7}$

We merge the OSS data with the MOF data by the code of the program-university pair that the student is admitted to. We exclude students who were admitted to Open University programs since these are part-time distance education programs with very low per student subsidies. We also exclude students at evening programs, since we cannot calculate the per student subsidy received by these students based on the data that we have. Students enrolled in either type of programs have usually jobs and careers. These restrictions bring the dataset down to 93,266 observations.

\section{Econometric framework}

We conceptualize the decision-making process of a student as follows: the student takes the OSS exam and observes his score. If he earns a score high enough to be admitted to a university, he decides whether he prefers to attend a public or a private university based on his own characteristics and his preferences for what these universities have to offer. If a student goes to a public university, he receives an implicit education subsidy from the government. We mainly estimate two models: a three stage Heckman selection model and a three-part model.

\subsection{The three-stage Heckman model}

The first stage of the selection model is a probit equation where the dependent variable "s" takes the value of 1 if the student is successful at the university entrance exam and earns the right to be placed at a programuniversity pair as a result of his university exam score and preference list. The unobserved latent variable is $s^{*}$.

$s^{*}=X_{1} \beta_{1}+\varepsilon_{1}$,

$s=\left\{\begin{array}{ll}1 & \text { if } s^{*} \geq 0 \\ 0 & \text { if } s^{*}<0\end{array} \quad\right.$ (for the entire sample)

The second stage is a probit equation where " $p$ " takes the value of 1 if the student was placed at a public university and 0 if placed at a private university as a result of his preference list and exam score. The sample is restricted to students who were successful in the exam. To control for the possible effect of selection into 'success', we use the inverse Mills ratio from the first stage as an explanatory variable in the second stage probit.

$p^{*}=X_{2} \beta_{2}+\varepsilon_{2}$,

$p=\left\{\begin{array}{ll}1 & \text { if } p^{*} \geq 0 \\ 0 & \text { if } p^{*}<0\end{array} \quad\right.$ (for the entire sample $s=1$ )

\footnotetext{
7 Based on the 1 USD $=1.34$ TL exchange rate in 2005, the highest fee was US\$19,776 and the smallest was US\$ 3184.
}

In stage three, the outcome " $c$ " is the amount of subsidy received by a public university student. We call this variable the 'per-student subsidy'. Here, our sample is restricted to students who entered a public university. To control for the possible effect of selection into 'public university', we use the inverse Mills ratio from the second stage in this regression.

$c=X_{3} \beta_{3}+\varepsilon_{3} \quad$ for the subsample $p=1$

The matrix $X_{3}$ includes:

(1) income measures, we use two alternative income measures in our estimations:

(a) 'Inincome' variable: In the survey, applicants are asked to choose one of the seven family income brackets. Hence, we generate an income variable that is equal to the natural logarithm of the midpoints of income brackets.

(b) income dummy variables: In order to capture the non-linear effects of income (and also not to impose any artificial income distance between applicants as in the 'Inincome' variable), we generate four income dummy variables based on income percentiles. ${ }^{8}$

(2) 'male' dummy variable, which is equal to one if the student is male, zero otherwise,

(3) the 'number of children' variable that indicates the number of children in the family,

(4) the 'science', 'social' and 'language' dummy variables that indicate the high school field of the student (the omitted category is 'Turkish and mathematics'),

(5) seven dummy variables for father's education, as explained in Section 4; the omitted category for education is illiterate,

(6) seven similarly defined dummies for mother's education.

(7) university/province/region level controls such as age of the university, cost of living index, region dummies.

One of our main interests is to find out how the financial resources of the family affect a student's chances of receiving higher education. We include family income and number of children in the family variables in our regressions, both of which determine the amount of resources that are available to the student.

We control for the gender of the student because both the success in the exam and the preference toward a private university can be influenced by gender. There is a large literature on the social, cultural and economic reasons behind son preference and its consequences on children's mortality and educational achievements (Ebenstein, 2010; Rosenzweig \& Schultz, 1982).

\footnotetext{
8 The categorical monthly family income variable takes seven values (less than 250 TL, 200-500 TL, 500-750 TL, 750-1000 TL, 1000-1500 TL, 1500-2000 TL and more than $2000 \mathrm{TL}$ ). The "Income1" dummy is one for the lowest income group (37\% of the population), "Income2" dummy is one for the 200-500 TL group (40\% of the population), "Income3" dummy is one for $500-750 \mathrm{TL}$ ( $13 \%$ of the population) and "Income4" dummy is one for more than $750 \mathrm{TL}$ income group (the richest $10 \%$ of the population). The highest three income brackets are grouped into Income 4 dummy variable due to their low observation frequency.
} 
Tansel (2002) finds a larger effect of family income on schooling of girls than that of boys in primary and secondary education in Turkey. Hence, we include the gender control in our regressions to account for the possibility that the willingness to pay for the education of a son is greater than that of a daughter, which would affect both the exam success of a student and the likelihood of attending a private university.

Parental education variables are included in the regressions as they are considered to be good indicators of both ability and socioeconomic status. Income is another indicator of socioeconomic status, and probably of ability; however there are reasons to prefer education as a measure of the social position of a student's family. As written by Lemelin (1992, p. 178), "First, education and social position are highly correlated; education has been used to estimate permanent income in economics, and social prestige of occupation in sociology. Second, it can be assumed that the education level of parents is better known than their income by university students."

The student's high school field ('Science', 'Social' and 'Language', with 'Turkish-Math' (TM) field omitted) are controlled for since there might be selection at the time the student chooses his high school field and these variables might affect the probability of success. For instance, higher ability students might choose to be in the 'Science' field while others may prefer the broader 'Social Science' or 'TM' fields. It is likely that only students who are genuinely interested in languages choose to be in the 'Language' field. These variables can also influence the student's public university choice since most majors are offered by public universities whereas private universities may choose to specialize in certain programs.

In the third stage estimation, we are interested in determining how per student subsidy differs across students with different backgrounds, controlling for university level variables which we think influence the amount of funds transferred to the university. The amount of public funds spent on a university may depend on cost related factors. In some parts of Turkey, providing education is more costly due to severe weather conditions in long winters. The age of the university could be another important factor. Older, historical buildings are usually more expensive to maintain. Furthermore, in large and industrialized cities where the average cost of living is higher, one would expect labor and material to be more expensive. To account for these effects on per student subsidy, we control for the age of the university and its square, the cost of living index and geographical region dummies.

The matrix $X_{2}$ includes all variables listed under points 1 through 6 above and a dummy variable that indicates whether the student's father works in the public sector. This variable is used as an exclusion restriction in the per student subsidy equation in stage 3 . We assume that this variable affects the student's preferences toward getting an education from a public university, but has no direct effect on the subsidy she receives from the public university. Caner and Okten (2010) find that in Turkey, students whose fathers are public sector employees are more likely to choose majors that lead to careers in the public sector.
The matrix $X_{1}$ includes all variables in matrix $X_{2}$ besides two variables. The first of these variables is 'Inpopulation', defined as the logarithm of the population of the area in which the student went to high school. The population variable is used as an indicator of the learning resources (such as high quality schools, private tutoring centers and libraries) that the student has access to while in high school. The other is 'times exam taken', defined as the number of times that the student has taken the exam. It is controlled for in the first stage since it influences the chances of success via two channels: first, repeaters may be less able students; second, repeaters may be more willing to enter university and make their choices accordingly, while first time exam takers may be more comfortable with taking the risk of failure and may target highly demanded programs. Therefore, the direction of influence on success is ambiguous. These variables are used as exclusion restrictions in the public university equation in stage 2. Our assumption here is that these variables affect the student's probability of success in the exam, but have no direct effect on the probability that she is placed at a public university. ${ }^{9}$

\subsection{The multinomial probit model}

The three-stage Heckman model does not help us rank the three groups (those who fail in the exam, public university students and private university students) according to family income. To detect this ranking, we conduct a multinomial probit analysis where the dependent variable takes three values: public university entrance, private university entrance and failure in the exam (the base category).

\subsection{The three-part model}

In studies related to ours, researchers have used the 'two-part model' to estimate similar equations. For example, Liu et al. (2006) has two equations, one for attending college and the other for attending a public university conditional on attending college. They state that they have no good exclusion restrictions and therefore estimate these equations by using the 'twopart model' as in Leung and Yu (1996) instead of the Heckman type selection model. Although we do have good candidates for exclusion restrictions, we use a 'three-part model' for two reasons. One is comparability with the literature. The other is the ease of computing the overall marginal effects from the three-part model. The selection model yields the marginal effects at each

\footnotetext{
${ }^{9}$ One can develop arguments against this assumption and argue that our exclusion restrictions are weak in controlling for selection. For example, the "Inpopulation" variable might have a direct effect on preferences for a private versus a public university since private universities were located only in the three largest cities in 2002. Similarly, if repeat takers prefer to wait and retake the exam in order to have another chance to be admitted to a well-known public university, the "times exam taken" variable might have a direct effect on preferences for a public university in addition to its indirect effect via success in the exam.
} 
step separately; the three-part model can be used to compute the overall impact of a small change in an explanatory variable on per student subsidy received by an average exam taker in the country.

The model consists of the same three Eqs. (1)-(3) and estimated for the same samples as described above, except that there is no selection correction. The equations are estimated separately, Eqs. (1) and (2) by probit and (3) by OLS. To receive subsidy, a student has to be placed at a public university. Therefore, the expected value of per student subsidy among exam takers is expressed as the product of the probability of success, the probability of public university attendance among those who succeed in the exam and the expected value of per student subsidy among those attending a public university:

$E(c)=\Phi\left(X_{1} \beta_{1}\right) \Phi\left(X_{2} \beta_{2}\right) X_{3} \beta_{3}$,

where $\Phi($.$) shows the cumulative normal distribution$ function.

With the three-part model, we can estimate the marginal effect of each control variable easily without having to deal with the selection correction. We derive the marginal effects in a similar way to Dow and Norton (2003), by taking the derivative of (4) with respect to a particular explanatory variable. The marginal effect of a variable $X_{j}$ is:

$$
\begin{aligned}
\frac{\partial E(c)}{\partial X_{j}}= & \phi\left(X_{1} \beta_{1}\right) \beta_{1 j} \Phi\left(X_{2} \beta_{2}\right) X_{3} \beta_{3} \\
& +\Phi\left(X_{1} \beta_{1}\right)\left\{\beta_{2 j} \phi\left(X_{2} \beta_{2}\right) X_{3} \beta_{3}+\Phi\left(X_{2} \beta_{2}\right) \beta_{3 j}\right\}
\end{aligned}
$$

where $\Phi($.$) shows the normal density function and \Phi($. shows the cumulative normal distribution function. The derivative is evaluated at mean values of $X_{1} \beta_{1}, X_{2} \beta_{2}$, and $X_{3} \beta_{3}$. In this sense, these marginal effects tell us the overall impact of a small change in an explanatory variable on per student subsidy received by an average exam taker in the country, whereas the estimates in the Heckman model belong to the sample for which the equation of interest is estimated for. Standard errors of marginal effects are estimated via bootstrapping with 50 replications.

Table 4

\begin{tabular}{|c|c|c|c|c|c|c|c|}
\hline \multirow[t]{2}{*}{ Type of variables } & \multirow[t]{2}{*}{ Variables } & \multicolumn{3}{|c|}{ University entrance } & \multicolumn{3}{|c|}{ Public university } \\
\hline & & $\begin{array}{l}\text { Coef. } \\
\text { (1a) }\end{array}$ & $\begin{array}{l}\mathrm{SE} \\
(1 \mathrm{~b})\end{array}$ & $\begin{array}{l}\mathrm{ME} \\
(1 \mathrm{c})\end{array}$ & $\begin{array}{l}\text { Coef. } \\
(2 \mathrm{a})\end{array}$ & $\begin{array}{l}\text { SE } \\
(2 \mathrm{~b})\end{array}$ & $\begin{array}{l}\mathrm{ME} \\
(2 \mathrm{c})\end{array}$ \\
\hline \multirow[t]{3}{*}{ Family resources } & Lnincome & $0.037^{* * *}$ & 0.008 & 0.010 & $-0.585^{* * *}$ & 0.025 & -0.090 \\
\hline & Male & -0.010 & 0.01 & -0.003 & $-0.181^{* * *}$ & 0.028 & -0.028 \\
\hline & Number of children & $-0.047^{* * *}$ & 0.005 & -0.012 & $0.058^{* * *}$ & 0.019 & 0.009 \\
\hline \multirow[t]{3}{*}{ High school field } & Science & $0.529^{* * *}$ & 0.013 & 0.153 & $-0.236^{* *}$ & 0.102 & -0.038 \\
\hline & Social & $-0.280^{* * *}$ & 0.016 & -0.067 & 0.099 & 0.088 & 0.014 \\
\hline & Language & $0.357^{* * *}$ & 0.014 & 0.100 & $-0.325^{* * *}$ & 0.077 & -0.055 \\
\hline \multirow{7}{*}{$\begin{array}{l}\text { Father's education } \\
\text { variables }\end{array}$} & Literate & 0.005 & 0.043 & 0.001 & -0.010 & 0.149 & -0.002 \\
\hline & Primary school graduate & 0.036 & 0.036 & 0.009 & 0.153 & 0.132 & 0.023 \\
\hline & Junior high school graduate & $0.062^{*}$ & 0.039 & 0.016 & 0.121 & 0.139 & 0.018 \\
\hline & High school graduate & $0.123^{* * *}$ & 0.038 & 0.033 & 0.028 & 0.139 & 0.004 \\
\hline & Junior college graduate & $0.199^{* * *}$ & 0.044 & 0.055 & -0.067 & 0.152 & -0.011 \\
\hline & College graduate & $0.358^{* * *}$ & 0.041 & 0.103 & $-0.520^{* * *}$ & 0.154 & -0.097 \\
\hline & Master's or Ph.D. degree & $0.613^{* * *}$ & 0.061 & 0.197 & $-0.977^{* * *}$ & 0.187 & -0.255 \\
\hline \multirow{7}{*}{$\begin{array}{l}\text { Mother's education } \\
\text { variables }\end{array}$} & Literate & 0.007 & 0.023 & 0.002 & $-0.142^{* *}$ & 0.083 & -0.024 \\
\hline & Primary school graduate & 0.023 & 0.018 & 0.006 & $-0.193^{* * *}$ & 0.069 & -0.031 \\
\hline & Junior high school graduate & $0.054^{* *}$ & 0.026 & 0.014 & $-0.358^{* * *}$ & 0.085 & -0.067 \\
\hline & High school graduate & $0.220^{* * * *}$ & 0.024 & 0.061 & $-0.658^{* * *}$ & 0.091 & -0.131 \\
\hline & Junior college graduate & $0.294^{* * * *}$ & 0.033 & 0.085 & $-0.540^{* * *}$ & 0.11 & -0.113 \\
\hline & College graduate & $0.391^{* * *}$ & 0.032 & 0.117 & $-0.841^{* * *}$ & 0.114 & -0.197 \\
\hline & Master's or Ph.D. degree & $0.745^{* * *}$ & 0.098 & 0.249 & $-1.413^{* * *}$ & 0.184 & -0.427 \\
\hline \multirow{9}{*}{$\begin{array}{l}\text { Other control } \\
\text { variables }\end{array}$} & Father's public sector status & $-0.086^{* * *}$ & 0.013 & -0.022 & $0.529^{* * * *}$ & 0.038 & 0.072 \\
\hline & Number of times exam taken & $-0.076^{* * *}$ & 0.005 & -0.020 & & & \\
\hline & Lnpopulation & $0.020^{* * *}$ & 0.003 & 0.005 & & & \\
\hline & Constant & $-1.373^{* * *}$ & 0.065 & & $7.084^{* * *}$ & 0.476 & \\
\hline & Mills1 & & & & $-1.478^{* * * *}$ & 0.241 & \\
\hline & Chi/ $F$ squared & 8100.7 & & & 1749.77 & & \\
\hline & log likelihood & $-41,693$ & & & -5597.5 & & \\
\hline & $R$-squared & 0.1 & & & 0.173 & & \\
\hline & Number of observations & 93,266 & & & 18,464 & & \\
\hline
\end{tabular}

Regression results on university attendance and public university attendance.

Source: Authors' calculations.

Notes: 'Coef.' is the estimated coefficient, 'SE' is the robust standard error of the coefficient, 'ME' is the marginal effect of an explanatory variable on the dependent variable.

* Statistical significance at $10 \%$.

** Statistical significance at $5 \%$.

*** Statistical significance at $1 \%$. 


\section{Results and discussion}

\subsection{The three-stage Heckman model}

\subsubsection{Stage 1}

In the first stage of the Heckman selection model, we estimate Eq. (1) by probit. In Table 4, we observe that family income, represented by the 'Inincome' variable has a positive and statistically significant effect on university entrance (column 1a). An approximately ten percent increase in family income increases the probability of university entrance by ten percentage points (column 1c). ${ }^{10}$ Number of children in the family as a measure of resources available to the student has a negative and significant effect on the probability of success while sex of the student does not have a statistically significant effect.

Parental education appears to be a very important determinant of university entrance. Students whose mothers (fathers) had high school education were 4.7 (1.7) percentage points more likely to enter university, both relative to having a junior high school education or less. As compared to students whose parents received a high school education or less, students whose mothers (fathers) received a four year college education were 5.6 (7.0) percentage points more likely to enter university. Similar to some studies on human capital (Liu et al., 2006; Behrman, 1999), we also find that, in general, mother's education level is economically more significant than father's educational attainment. However, we fail to reject the equality of father's and mother's relevant educational attainments in all categories except for high school graduates in statistical tests of relevant coefficients. ${ }^{11}$

The number of tries in the exam has a negative and significant effect on success in university entrance; hence we interpret this variable as a measure of ability. As expected, the population of the city where the student went to high school has a positive and significant effect. Population is a relevant measure of both the availability of private tutoring centers that provide preparation for the exam and the quality of high schools. ${ }^{12}$ These variables are also our exclusion restrictions and hence excluded from the second stage probit. We found that the two variables excluded from the first stage regression are jointly significant with a Chi-square distributed Wald test statistic of 313.79 and a $p$-value that is almost zero.

\subsubsection{Stage 2}

In the second stage, a probit regression, the outcome is entering a public university. We observe it for students

\footnotetext{
${ }^{10}$ Although in a different setting, Tansel (2002) finds similarly that permanent household income has a strong positive effect on school attainment at primary, middle and high school levels in Turkey.

11 Tansel (2002) studies school attainment of girls and boys separately and finds that the father's and the mother's education coefficient estimates were not significantly different from each other in most samples.

12 Tansel and Bircan (2005) find, in a similar probit regression, the same marginal effect of family income on the probability of success in the exam. Their results with regard to the effects of mother's and father's years of education, the population of the city where the student went to high school, and father's wage earner status are similar to ours.
}

who have succeeded in the university entrance exam. Hence we use the inverse Mills ratio (mills1) from the first stage as an explanatory variable in the second stage probit. In Table 4 , columns (2a)-(2c), we present our results. We observe that contrary to the results in Liu et al. (2006), students from higher income families are more likely to go to private universities. A one percent increase in family income decreases the probability of going to a public university by 9 percentage points. This is a positive result in terms of public policy. We attribute the difference in findings from Liu et al. (2006) to the existence of price controls in the Taiwanese private higher education market and the lack of it in Turkey. The Turkish private higher education sector is able to provide a product that is perceived to be of high quality and hence attracts students from high income families. This finding contradicts also with Rozada and Menendez (2002) study on Argentina where public and private university students have the same characteristics and both come from the highest income families. Another finding is that, as expected, students that come from families with more children are more likely to go to public universities than private ones, since the number of children in the family decreases per student resource availability. Interestingly, male students are more likely to go to private universities than public ones. This result is consistent with the earlier results in the literature on families' willingness to expend more resources on male children.

We also observe that students with better educate parents are more likely to go to private universities. Compared to students whose mothers received only primary education, those whose mothers received a four year bachelor's degree are 16.6 percentage points more likely to enter a private university than a public university (Table 4, column 2c). The finding that students with high income and better educated parents are more likely to enter private universities implies that these universities are prestigious. These universities offer a scholarship (tuition-free education plus a stipend) to a small group of students (based on merit) while charging the majority of their students the full tuition. The students on scholarship are expected to motivate others to study harder. We exclude these students from our sample since they neither receive an implicit government subsidy nor pay tuition. We deduce that the combined effect of the existence of this group of students and the lack of a priceceiling on tuition help maintain the quality of education provided by private universities.

Interestingly, father's public sector employment status increases the probability of entering a public university as opposed to a private university by 7.2 percentage points (Table 4, column 2c), although its effect on success at university entrance was negative and significant (Table 4 , column 1a). This result seems to support our assumption that father's public sector status positively affects the student's preference toward getting an education from a public university.

\subsubsection{Stage 3}

In stage 3, where the outcome is per-student subsidy from government, our sample is restricted to students who entered a public university. In this stage, in addition to the socio-demographic variables, we control for the age of the 
Table 5

Regression results on per-student subsidy.

\begin{tabular}{|c|c|c|c|c|c|c|c|c|c|c|}
\hline & Variables & (1) Coef. & (2) SE & (3) Elasticity & (4) Coef. & (5) SE & (6) Elasticity & (7) Coef. & (8) SE & (9) Elasticity \\
\hline \multirow[t]{4}{*}{ Family resources } & Lnincome & $857.076^{* * *}$ & 60.599 & 0.249 & $233.008^{* * *}$ & 61.549 & 0.068 & $280.835^{* * *}$ & 63.557 & 0.082 \\
\hline & Male & $688.335^{* * *}$ & 54.036 & 0.200 & $168.145^{* * *}$ & 55.176 & 0.049 & $846.709^{* * * *}$ & 331.830 & 0.246 \\
\hline & Lnincome $\times$ Male & No & & & No & & & $-117.006^{* *}$ & 58.478 & -0.034 \\
\hline & Number of children & $70.620^{* * *}$ & 27.122 & 0.021 & $68.775^{* * *}$ & 26.431 & 0.020 & $67.678^{* * *}$ & 26.407 & 0.020 \\
\hline \multirow{3}{*}{ High school field } & Science & No & & & $1969.515^{* * *}$ & 66.060 & 0.573 & $1977.422^{* * *}$ & 66.872 & 0.575 \\
\hline & Social & No & & & $408.068^{* * *}$ & 46.451 & 0.119 & $400.582^{* * *}$ & 47.050 & 0.117 \\
\hline & Language & No & & & $195.278^{* * *}$ & 31.962 & 0.057 & $196.733^{* * *}$ & 32.021 & 0.057 \\
\hline \multirow{7}{*}{$\begin{array}{l}\text { Father's education } \\
\text { variables }\end{array}$} & Literate & -81.140 & 225.152 & -0.024 & -134.278 & 222.007 & -0.039 & -120.684 & 221.394 & -0.035 \\
\hline & Primary school graduate & $-311.715^{*}$ & 208.188 & -0.091 & -159.778 & 204.805 & -0.046 & -140.396 & 204.300 & -0.041 \\
\hline & Junior high school graduate & $-517.289^{* * * *}$ & 216.184 & -0.150 & -267.862 & 212.134 & -0.078 & -245.990 & 211.353 & -0.072 \\
\hline & High school graduate & $-471.969^{* *}$ & 219.056 & -0.137 & -159.688 & 215.444 & -0.046 & -135.946 & 214.589 & -0.040 \\
\hline & Junior college graduate & $-478.652^{* *}$ & 242.841 & -0.139 & -41.740 & 238.041 & -0.012 & -15.714 & 237.276 & -0.005 \\
\hline & College graduate & $409.751^{* *}$ & 226.978 & 0.119 & $341.374^{*}$ & 223.063 & 0.099 & $361.079^{*}$ & 222.055 & 0.105 \\
\hline & Master's or Ph.D. degree & $1516.058^{* * *}$ & 305.942 & 0.441 & $955.999^{* * *}$ & 293.950 & 0.278 & $969.592^{* * *}$ & 293.039 & 0.282 \\
\hline \multirow{7}{*}{$\begin{array}{l}\text { Mother's education } \\
\text { variables }\end{array}$} & Literate & $165.769^{*}$ & 104.688 & 0.048 & 59.911 & 102.951 & 0.017 & 66.300 & 103.044 & 0.019 \\
\hline & Primary school graduate & $305.254^{* * * *}$ & 94.839 & 0.089 & $161.720^{* *}$ & 92.791 & 0.047 & $171.098^{* *}$ & 93.081 & 0.050 \\
\hline & Junior high school graduate & $532.706^{*+*}$ & 132.905 & 0.155 & $249.110^{* *}$ & 130.248 & 0.073 & $254.933^{* *}$ & 130.298 & 0.074 \\
\hline & High school graduate & $986.503^{* * *}$ & 122.543 & 0.287 & $487.637^{* * *}$ & 121.263 & 0.142 & $487.814^{* * *}$ & 121.228 & 0.142 \\
\hline & Junior college graduate & $755.053^{* * *}$ & 169.982 & 0.220 & $600.796^{* * *}$ & 164.578 & 0.175 & $604.279^{* * *}$ & 164.521 & 0.176 \\
\hline & College graduate & $1405.696^{* * *}$ & 157.266 & 0.409 & $737.471^{* * *}$ & 153.046 & 0.215 & $733.475^{* * * *}$ & 153.004 & 0.213 \\
\hline & Master's or Ph.D. degree & $2683.989^{* * *}$ & 333.806 & 0.781 & $1136.465^{* * *}$ & 297.314 & 0.331 & $1122.490^{* * *}$ & 296.615 & 0.326 \\
\hline \multirow{5}{*}{$\begin{array}{l}\text { University and } \\
\text { region variables }\end{array}$} & Age (of the University) & $68.831^{* * * *}$ & 5.923 & 0.020 & $68.432^{* * * * * *}$ & 5.856 & 0.020 & $68.347^{* * *}$ & 5.857 & 0.020 \\
\hline & Age squared & $-0.865^{* * *}$ & 0.069 & 0.000 & $-0.854^{* * *}$ & 0.069 & -0.0002 & $-0.852^{* * *}$ & 0.069 & 0.000 \\
\hline & Cost of living index & $71.772^{* * * *}$ & 4.438 & 0.021 & $69.078^{* * *}$ & 4.350 & 0.020 & $68.841^{* * *}$ & 4.359 & 0.020 \\
\hline & Region dummies & Yes & & & Yes & & & Yes & & 0.020 \\
\hline & $\begin{array}{l}\text { Mills2 } \\
R \text {-squared }\end{array}$ & $\begin{array}{l}-5960.48^{* * *} \\
0.108\end{array}$ & 282.806 & -1.734 & $\begin{array}{l}-1398.94^{* * *} \\
0.159\end{array}$ & 291.703 & -0.407 & $\begin{array}{l}-1352.31^{* * *} \\
0.159\end{array}$ & 295.626 & -0.393 \\
\hline
\end{tabular}

Source: Authors' calculations.

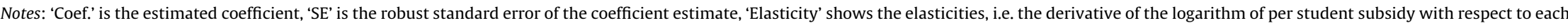
explanatory variable. Regressions include a constant term. The number of observations is 16,251

Statistical significance at $10 \%$

** Statistical significance at $5 \%$.

*** Statistical significance at $1 \%$ 
university and its square, the cost of living index and geographical region dummies. We also use the inverse Mills ratio (Mills2) from the second stage.

Table 5 reports the results for three different specifications. In all specifications we find that students from higher income families receive higher subsidies from the government. The first specification includes all the explanatory variables from the second stage, except for father's public sector status and high school field dummies. The second specification includes high school field dummies in addition to all the control variables in the first specification. Controlling for field dummies allows one to estimate the effect of income within fields. However, it is clear that there can be important subsidy differences among programs that students from different fields are likely to enter. For example, students in the science field may choose expensive programs such as engineering and medicine as opposed to those in the TM field who may choose less expensive programs such as economics. ${ }^{13}$ Including field dummies in the regression might underestimate the effect of income on placement in higher subsidy programs. This is indeed what we find. A one percent increase in family income increases per student subsidy by 6.8 percentage points (column 6 ) when field dummies are controlled for, but by 24.9 percentage points (column 3 ) when they are left out.

We observe that students whose mothers are better educated receive a higher per student subsidy. Subsidy received by students whose mothers have a four-year bachelor's degree is 40.9 percent higher (21.5 percent in specification 2) (columns 3 and 6 , respectively) compared to students whose mothers are illiterate and 12.2 percent higher subsidy ( 7.3 percent in specification 2 ) compared to students whose mothers are high school graduates. Interestingly, male students and those from families with more children receive higher subsidies from the government. Being male increases the per-student subsidy of the placed program by 20 percentage points ( 4.9 percentage points in specification 2).

We now examine the effects of cost related (supply side) variables on the level of per-student subsidies. There is a nonlinear (concave) relationship between the age of the university and the subsidy per student (columns 1 and 4 ). The effect of age is positive for universities younger than 75-80 years, which is the case for almost all Turkish universities. Older universities do spend more money per student. The age of the university may represent both the extent of costs required to maintain the buildings and the reputation of the university. The Ministry of Finance may be inclined to provide higher financial support to better known, more reputable universities, although this is never officially acknowledged. The province level cost of living index, adopted from Tuyluoglu and Albayrak (2010), is the average price of 375 goods and services in a group of provinces divided by the average of those prices over all provinces. The six most expensive provinces are İstanbul, Ankara, İzmir,

\footnotetext{
${ }^{13}$ Indeed, average per student subsidy in the science field is substantially higher than the figure in the TM field (4629 TL versus $2319 \mathrm{TL}$; the two are found to be statistically different based on a $t$-test of means).
}

Bolu, Kocaeli and Sakarya, the first three of which are the biggest cities and the other three industrial centers. The index enters the regression with a positive sign, as expected, and the effect is statistically significant. There are seven geographical regions in Turkey. The Southeast Anatolia region, the region with the lowest level of economic development has the highest subsidy per student, controlling for all other factors (The Marmara region is the excluded dummy). One explanation can be that relatively harsher weather conditions in the eastern regions require higher per student subsidies from government. A second explanation is that the government may have chosen to provide more support to universities in less developed regions.

In specification 3, we examine how the effect of family income on per student subsidy varies across genders. In a developing and relatively traditional country such as Turkey, we would expect sons to be supported by their families at socio-economic levels, but daughters to have a higher likelihood of receiving support in higher socioeconomic groups. To test this, we add in specification 4 the 'Lnincome $\times$ Male' interaction term. This term has a negative sign (column 9), therefore family income has a bigger impact on the subsidy that a female student receives compared to a male student, as expected. Furthermore, we question whether our results are driven by the female students in our dataset. To check this, we run the per student regression for males and females separately. Since we obtain similar results by excluding females from our sample (results are not shown but available from authors upon request), we have more confidence in our findings.

Another test we perform is to replace 'Inincome' variable with income dummy variables. The purpose is to see the non-linear effect of income and to recognize that a family belongs to an income group without imposing an assumption on the income distance between families. We generate four income dummies based on income percentiles. Interestingly, we do observe non-linear effects of income in the first stage probit estimation (success). Relative to the omitted Income1 dummy, the Income 2 dummy variable does not have a significant effect; but Income3 is negative and significant and Income 4 is positive and significant. Hence, at the top $10 \%$ of the income distribution, income has a positive effect on the probability of success in the exam. The effect of income on the public versus private university choice and the matching of university/school specific government subsidies to public university entrants are consistent with earlier results where all income dummies are statistically significant. The income dummies are increasingly more negative in stage 2 (higher income students go to private universities) and increasingly more positive in stage 3 (higher income students receive higher subsidy). These results are not shown but available from authors upon request.

\subsection{The multinomial probit model}

In the multinomial probit analysis, the dependent variable takes three values: public university entrance, private university entrance and failure in the exam (the base category). The results, presented in Table 6 , tell us that on average public university students are poorer than 
Table 6

Multinomial probit estimates for failure in the exam, public university entrance and private university entrance (base category: failure).

\begin{tabular}{|c|c|c|c|c|c|c|c|}
\hline \multirow[t]{2}{*}{ Type of variables } & \multirow[t]{2}{*}{ Variables } & \multicolumn{3}{|c|}{ Outcome: Public university entrance } & \multicolumn{3}{|c|}{ Outcome: Private university entrance } \\
\hline & & $\begin{array}{l}\text { Coefficient } \\
\text { estimate }\end{array}$ & $\begin{array}{l}\text { Standard } \\
\text { error }\end{array}$ & $Z$ & $\begin{array}{l}\text { Coefficient } \\
\text { estimate }\end{array}$ & $\begin{array}{l}\text { Standard } \\
\text { error }\end{array}$ & $Z$ \\
\hline Family resources & $\begin{array}{l}\text { Logarithm of family income } \\
\text { Male } \\
\text { Number of children }\end{array}$ & $\begin{array}{l}-0.036 \\
-0.035 \\
-0.064\end{array}$ & $\begin{array}{l}0.011 \\
0.015 \\
0.008\end{array}$ & $\begin{array}{l}-3.18^{* * *} \\
-2.35^{* * *} \\
-8.50^{* * *}\end{array}$ & $\begin{array}{r}0.519 \\
0.122 \\
-0.062\end{array}$ & $\begin{array}{l}0.021 \\
0.028 \\
0.015\end{array}$ & $\begin{array}{r}25.05^{* * *} \\
4.37^{* * *} \\
-4.13^{* * *}\end{array}$ \\
\hline High school field & $\begin{array}{l}\text { Science } \\
\text { Social } \\
\text { Language }\end{array}$ & $\begin{array}{l}0.788 \\
-0.420 \\
0.519\end{array}$ & $\begin{array}{l}0.019 \\
0.023 \\
0.020\end{array}$ & $\begin{array}{r}40.91^{* * *} \\
-17.91^{* * *} \\
26.27^{* * *}\end{array}$ & $\begin{array}{r}0.290 \\
-0.126 \\
0.309\end{array}$ & $\begin{array}{l}0.038 \\
0.044 \\
0.036\end{array}$ & $\begin{array}{r}7.71^{* * *} \\
-2.88^{* * * *} \\
8.47^{* * *}\end{array}$ \\
\hline $\begin{array}{l}\text { Father's education } \\
\text { variables }\end{array}$ & $\begin{array}{l}\text { Literate } \\
\text { Primary school graduate } \\
\text { Junior high school graduate } \\
\text { High school graduate } \\
\text { Junior college graduate } \\
\text { College graduate } \\
\text { Master's or Ph.D. degree }\end{array}$ & $\begin{array}{l}0.010 \\
0.071 \\
0.107 \\
0.193 \\
0.294 \\
0.450 \\
0.696\end{array}$ & $\begin{array}{l}0.060 \\
0.051 \\
0.054 \\
0.054 \\
0.062 \\
0.058 \\
0.088\end{array}$ & $\begin{array}{l}0.16 \\
1.39^{*} \\
1.96^{* *} \\
3.55^{* * *} \\
4.76^{* * *} \\
7.77^{* * *} \\
7.94^{* * *}\end{array}$ & $\begin{array}{r}-0.035 \\
-0.175 \\
-0.171 \\
-0.076 \\
0.021 \\
0.474 \\
0.918\end{array}$ & $\begin{array}{l}0.137 \\
0.121 \\
0.128 \\
0.126 \\
0.138 \\
0.129 \\
0.150\end{array}$ & $\begin{array}{l}-0.26 \\
-1.44^{*} \\
-1.34^{*} \\
-0.60 \\
0.15 \\
3.69^{* * *} \\
6.14^{* * *}\end{array}$ \\
\hline $\begin{array}{l}\text { Mother's education } \\
\text { variables }\end{array}$ & $\begin{array}{l}\text { Literate } \\
\text { Primary school graduate } \\
\text { Junior high school graduate } \\
\text { High school graduate } \\
\text { Junior college graduate } \\
\text { College graduate } \\
\text { Master's or Ph.D. degree }\end{array}$ & $\begin{array}{l}0.010 \\
0.034 \\
0.066 \\
0.266 \\
0.418 \\
0.475 \\
0.763\end{array}$ & $\begin{array}{l}0.033 \\
0.026 \\
0.037 \\
0.035 \\
0.048 \\
0.047 \\
0.142\end{array}$ & $\begin{array}{c}0.31 \\
1.30^{*} \\
1.76^{* *} \\
7.69^{* * *} \\
8.74^{* * *} \\
10.18^{* * *} \\
5.37^{* * *}\end{array}$ & $\begin{array}{l}0.055 \\
0.100 \\
0.235 \\
0.542 \\
0.465 \\
0.758 \\
1.390\end{array}$ & $\begin{array}{l}0.077 \\
0.064 \\
0.080 \\
0.075 \\
0.092 \\
0.085 \\
0.163\end{array}$ & $\begin{array}{l}0.72 \\
1.56^{*} \\
2.94^{* * *} \\
7.27^{* * *} \\
5.03^{* * *} \\
8.94^{* * *} \\
8.54^{* * *}\end{array}$ \\
\hline $\begin{array}{l}\text { Other control } \\
\text { variables }\end{array}$ & $\begin{array}{l}\text { Father's public sector status } \\
\text { Number of times exam taken } \\
\text { Lnpopulation } \\
\text { Constant }\end{array}$ & $\begin{array}{l}-0.121 \\
0.021 \\
-0.036 \\
-1.428\end{array}$ & $\begin{array}{l}0.007 \\
0.004 \\
0.019 \\
0.094\end{array}$ & $\begin{array}{r}-17.28^{* * *} \\
5.32^{* * *} \\
-1.91^{* *} \\
-15.20^{* * *}\end{array}$ & $\begin{array}{r}0.002 \\
0.079 \\
-0.494 \\
-6.770\end{array}$ & $\begin{array}{l}0.013 \\
0.008 \\
0.035 \\
0.199\end{array}$ & $\begin{array}{r}0.14 \\
9.28^{* * *} \\
-14.12^{* * *} \\
-34.03^{* * *}\end{array}$ \\
\hline $\begin{array}{l}\text { Log likelihood } \\
N \\
\text { Wald Chi-squared }\end{array}$ & & $\begin{array}{l}-47,238.754 \\
93,266 \\
10,858.53\end{array}$ & & & & & \\
\hline
\end{tabular}

Source: Authors' calculations.

* Statistical significance at $10 \%$.

** Statistical significance at $5 \%$.

*** Statistical significance at $1 \%$.

those who fail in the exam. So, in this sense, public provision of higher education supports the poor families. The OSS is a great opportunity for poor but bright and hardworking students to receive subsidized higher education. However, there are subtleties involved. First, public universities in Turkey do not form a homogenous group. A degree from a more prestigious public university leads to better employment opportunities. The fact that higher income students are more likely to attend higher subsidy and better-known universities indicate that there are regressive distributional effects of government subsidies for higher education among their recipients. Second, although on average public university students are poorer than those who fail in the exam, the parents of the earlier group have more education than parents of the latter. Since education is known to be a good indicator of socioeconomic status, the combined evidence suggests that the public university system in Turkey supports students from higher socio-economic groups.

\subsection{The three-part model}

In the three stage Heckman model the Mills' ratios were statistically significant in all regressions, which can be taken as evidence that there is selection. However, we think that it is worthwhile to consider an alternative approach using a 'three-part model'. This model is based on the idea that when the dependent variable is zero or missing for a high number of observations, it does not necessarily mean that there is a selection problem. In our case, it takes into account that only the students who are enrolled in a public university receive a positive subsidy, but no correction is made for selection bias.

In the three-part model we estimate the marginal effects of explanatory variables using the information from all three equations as shown by equation 5 and as explained in the econometric framework section. The marginal effects along with their standard errors and statistical significance levels are reported in Table 7. Since the entire sample is used to compute the marginal effects, the estimates tell us how much a small change in an explanatory variable would affect the amount of per student subsidy received by an average exam taker, different from the three-stage model. We use four different specifications. Specifications B and D exclude field dummies. Specifications $C$ and D replace logarithm of family income with income dummies.

In the three-part model, similar to the results from the selection model, we find that parental education positively affects the amount of subsidy received and that the effect is 
Table 7

Estimates of marginal effects in the three-part model.

\begin{tabular}{|c|c|c|c|c|c|c|c|c|c|}
\hline & \multirow[t]{2}{*}{ Variables } & \multicolumn{2}{|c|}{$\begin{array}{l}\text { Specification A (with } \\
\text { field dummies } \\
\text { in Eq. (3)) }\end{array}$} & \multicolumn{2}{|c|}{$\begin{array}{l}\text { Specification B } \\
\text { (without field } \\
\text { dummies in Eq. (3)) }\end{array}$} & \multicolumn{2}{|c|}{$\begin{array}{l}\text { Specification C } \\
\text { (with field dummies } \\
\text { in Eq. (3)) }\end{array}$} & \multicolumn{2}{|c|}{$\begin{array}{l}\text { Specification D } \\
\text { (without field } \\
\text { dummies in Eq. (3)) }\end{array}$} \\
\hline & & ME & SE & $\mathrm{ME}$ & SE & ME & SE & ME & SE \\
\hline \multirow[t]{6}{*}{ Family resources } & Logarithm of family income & -10.82 & $7.39^{*}$ & -13.99 & $8.59^{*}$ & - & & - & \\
\hline & Income2 & - & & - & & -17.06 & $9.69^{* *}$ & -8.31 & 7.09 \\
\hline & Income3 & - & & - & & -67.11 & $18.02^{* * *}$ & -51.19 & $22.56^{* *}$ \\
\hline & Income 4 & - & & - & & 41.77 & $27.19^{*}$ & 32.09 & $24.65^{*}$ \\
\hline & Male & -11.17 & 14.71 & 44.95 & $11.20^{* * *}$ & -12.83 & $9.41^{*}$ & 39.78 & $7.25^{* * *}$ \\
\hline & Number of children & -28.37 & $8.34^{* * *}$ & -27.56 & $5.45^{* * *}$ & -29.31 & $4.65^{* * *}$ & -25.90 & $5.53^{* * *}$ \\
\hline \multirow[t]{3}{*}{ High school field } & Science & 788.68 & $11.80^{* * *}$ & 455.73 & $6.46^{* * *}$ & 807.56 & $19.39^{* * *}$ & 447.35 & $13.91^{* * *}$ \\
\hline & Social & -212.12 & $10.58^{* * *}$ & -256.79 & $11.82^{* * *}$ & -214.12 & $15.22^{* * *}$ & -247.13 & $11.28^{* * *}$ \\
\hline & Language & 327.36 & $11.12^{* * *}$ & 292.05 & $14.25^{* * *}$ & 331.92 & $5.41^{* * *}$ & 281.86 & $13.47^{* * *}$ \\
\hline \multirow{7}{*}{$\begin{array}{l}\text { Father's education } \\
\text { variables }\end{array}$} & Literate & -20.15 & 51.02 & -11.41 & 54.72 & -19.93 & 46.35 & -0.47 & 27.85 \\
\hline & Primary school graduate & 28.29 & 51.30 & 45.84 & 47.17 & 24.62 & 34.16 & 43.78 & $27.55^{*}$ \\
\hline & Junior high school graduate & 38.22 & 35.42 & 41.85 & 47.26 & 33.74 & 44.31 & 43.62 & 40.24 \\
\hline & High school graduate & 105.03 & $56.39^{* *}$ & 107.98 & $24.02^{* * *}$ & 103.97 & $41.62^{* * *}$ & 116.67 & $50.98^{* *}$ \\
\hline & Junior college graduate & 193.35 & $37.51^{* * *}$ & 185.54 & $27.55^{* * *}$ & 192.14 & $32.44^{* * *}$ & 202.15 & $44.87^{* * *}$ \\
\hline & College graduate & 327.58 & $49.08^{* * *}$ & 334.36 & $44.92^{* * *}$ & 327.32 & $58.84^{* * *}$ & 351.41 & $62.40^{* * *}$ \\
\hline & Master's or Ph.D. degree & 578.05 & $50.64^{* * *}$ & 578.86 & $96.59^{* * *}$ & 567.74 & $64.65^{* * *}$ & 596.56 & $51.73^{* * *}$ \\
\hline \multirow{7}{*}{$\begin{array}{l}\text { Mother's education } \\
\text { variables }\end{array}$} & Literate & 2.01 & 19.34 & 12.70 & 21.17 & 7.22 & 13.27 & 3.53 & 33.51 \\
\hline & Primary school graduate & 30.08 & $13.98^{* *}$ & 52.37 & $20.12^{* * *}$ & 34.29 & $24.32^{*}$ & 41.80 & $27.77^{*}$ \\
\hline & Junior high school graduate & 46.38 & $25.38^{* *}$ & 73.08 & $32.43^{* *}$ & 54.32 & $18.40^{* * *}$ & 75.85 & $29.46^{* * *}$ \\
\hline & High school graduate & 198.80 & $25.32^{* * *}$ & 226.84 & $27.00^{* * *}$ & 204.36 & $38.36^{* * *}$ & 232.65 & $27.61^{* * *}$ \\
\hline & Junior college graduate & 314.97 & $26.36^{* * *}$ & 343.14 & $33.38^{* * *}$ & 325.66 & $23.09^{* * *}$ & 357.97 & $38.08^{* * *}$ \\
\hline & College graduate & 372.38 & $29.06^{* * *}$ & 414.69 & $49.64^{* * *}$ & 373.80 & $31.97^{* * *}$ & 435.79 & $23.52^{* * *}$ \\
\hline & Master's or Ph.D. degree & 642.43 & $71.10^{* * *}$ & 687.67 & $101.22^{* * *}$ & 625.34 & $65.39^{* * *}$ & 713.46 & $106.30^{* * *}$ \\
\hline Log likelihood & & $-216,793$ & & $-217,562$ & & $-218,946$ & & $-219,723$ & \\
\hline
\end{tabular}

Source: Authors' calculations.

Notes: The marginal effects are calculated based on the information from all three stages of regressions, as explained in the text. Standard errors of the marginal effects are estimated via bootstrapping. University and region variables are included in the subsidy per student equation. The number of observations is 93,266

* Statistical significance at $10 \%$.

** Statistical significance at $5 \%$

*** Statistical significance at $1 \%$.

statistically significant when parents have at least a junior high school degree. For example, the subsidy received by a student whose father is a college graduate is $327.58 \mathrm{TL}$ higher than a student whose father is illiterate (specification A). The corresponding figure for the effect of the mother having a college degree is higher, $372.38 \mathrm{TL}$. In all four specifications, we notice that the mother's education has a bigger effect on per student subsidy.

With regard to the effect of family income on per student subsidy received by an average exam taker, there are three opposing forces: students coming from higher income families, first, are more likely to succeed in the exam; second, are less likely to attend a public university; and third, receive a higher amount of subsidy. We observe the net effect of these three forces. When the level of income is used as a control variable, the net effect turns out to be negative at $10 \%$ significance level. In specifications $C$ and $\mathrm{D}$, we use income dummies and observe non-linear effects of income on per student subsidy. There is evidence for a U-shaped effect of income; the dummy variable 'Income3' is negative and significant, but 'Income4' is positive and significant. In other words at the highest income level (for the richest $10 \%$ of the population) the effect is positive and statistically significant, which suggests that students from the highest income families are more likely to attend universities that obtain a high amount of per student subsidy from the government.

The results show us that an average student in the entire sample receives a higher subsidy if that student comes from a lower income family. Yet, a student receives a higher subsidy if his parents have better education, which may be a more reliable indicator of socio-economic status. A student at the top $10 \%$ of the income distribution receives a higher subsidy. This is true despite the finding that richer students attend private universities. Since private university students receive zero subsidy, the result must be generated by students at the top $10 \%$ of the income distribution who attend public universities that offer a high subsidy per student.

We know that male students are less likely to go to a public university but when they do, they receive a higher subsidy. Therefore, in Table 7 we observe the net effect of these two forces. When the field dummies are excluded, the male dummy is positive and statistically significant (i.e. male students choose schools with higher per student subsidy, such as medicine and engineering). 
6.4. Through which channels does socio-economic background affect university entrance and public versus private university choice?

High-school students study hard and spend a lot of money to succeed in the university entrance exam since a university degree from a reputable university increases the chances of employment. We showed in Table $2 \mathrm{~b}$ that success rates rise with family income. In Turkey, tutoring centers are popular; those who have more financial resources can prepare for the exam better. Using the 1994 Household Expenditure Survey, Tansel and Bircan (2006) find that households with higher incomes and higher parental education levels devote more resources to private tutoring. Based on our dataset we find that private tutoring expenditures and family income are significantly correlated with a correlation coefficient of 0.45 . Furthermore, in a Tansel and Bircan (2006) style Tobit regression where private tutoring expenditures is regressed on income and other family characteristics, income is found to be positive and significant. (This regression, though not presented for brevity, is available upon request.) Therefore, one important channel through which having a richer family affects the probability of success in the exam is better preparation for the exam. ${ }^{14}$

A second channel through which income may affect university entrance is the way it shapes preferences for certain types of universities. In Appendix Table A1, we present the names of the universities that offer the highest per student subsidies. Most of the universities in the table are established and prestigious universities. Based on our observations and our experience we know that those who are admitted to these universities have a higher chance of obtaining a better job after graduation. Companies often list some of these universities in their advertisements for jobs. So, we conjecture that income and other socioeconomic characteristics affect not only the probability of success but also the type of university that a student chooses. Students with better background characteristics may have better information, via a better network, on what prestigious universities have to offer; they can have a preference for some amenities (such as social clubs and sports activities) that are more common in well-known universities. Some students with higher income and more educated families may prefer private universities to benefit from their smaller class sizes and better infrastructure. Hence preferences shaped by socio-economic characteristics also influence the university choice.

To present some evidence on how different groups of students compare to each other with respect to their characteristics, we plot in Fig. 1 the kernel density estimates of the estimated probability of success in Eq. (1), separately for those who are not placed, those

\footnotetext{
${ }^{14}$ Another channel could be that income influence the quality of the high school that the student attends. Hence family income may also play a role in tertiary level educational outcomes through its effect on secondary level educational outcomes. Rozada and Menendez (2002) find that low income students are excluded from higher education. We do not investigate here whether it is the case in Turkey. Such questions are beyond the scope of this paper and warrant further research.
}

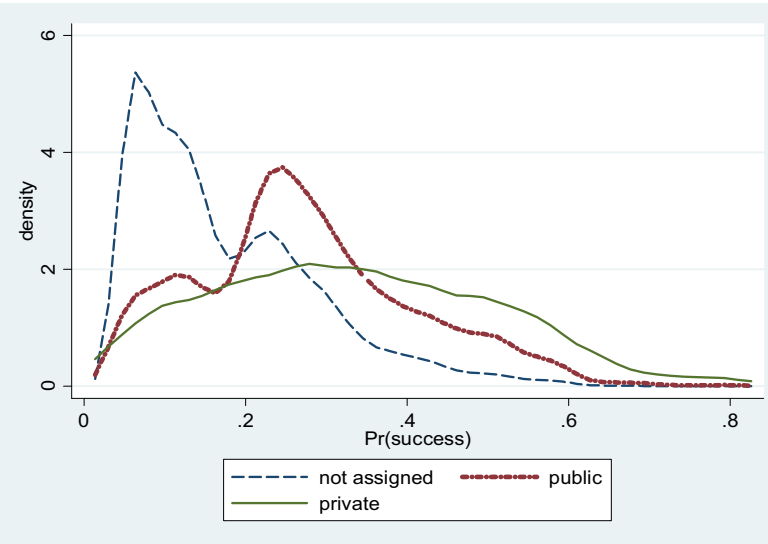

Fig. 1. The predicted probability of success versus its density (kernel density estimates).

Source: Authors' calculations.

placed in a public university and those placed in a private university. These probabilities are a weighted average of the students' characteristics in the $X_{1}$ matrix. Hence the density estimate is an estimate of the distribution of characteristics that yield success.

The figure clearly shows how students can be grouped according to their characteristics. Most of those who were not assigned to any program have characteristics that yield a low probability of success (Fig. 1, the hump around 0.1 success probability). Many public university students have characteristics that yield a higher probability of success (Fig. 1, the hump around 0.25). Therefore, many public university students have background characteristics that yield higher probability of success (such as higher income, better parental education) compared to those who are not assigned. Hence, we find further evidence that the publicly financed higher education system in Turkey supports the students with better socio-economic characteristics.

We also observe in Fig. 1 that there are at least two groups of public university students (the humps around 0.1 and 0.25 and others in the right tail of the density curve). Our regression analyses imply that among public university students higher subsidies accrue to students with characteristics that yield higher probability of success. Hence, we would guess that public university students in the right tail in Fig. 1 (who have distinctly better socio-economic characteristics compared to students who are not assigned) are the recipients of larger public subsidies.

In our regression analyses we established that better socio-economic characteristics increases the likelihood of going to a private university than a public one. However, it is interesting to observe in Fig. 1 that there is considerable overlap of the density curves of public and private university entrants. In other words, there are many public university students with characteristics that are very similar to private university students. We will examine the public policy implications of this observation in Section 7.

\section{Should students pay more for higher education?}

In Turkey, the fees that public university students pay are very low and constitute a very small portion of the total 
Table 8

Annual family income and private tutoring expenditures for various sub-samples in the 2002 survey (in 2005 prices).

\begin{tabular}{|c|c|c|c|c|c|}
\hline \multirow[t]{2}{*}{ Variable } & \multicolumn{2}{|c|}{ Family income } & \multicolumn{2}{|c|}{ Tutoring expenditure } & \multirow[t]{2}{*}{$N$} \\
\hline & Mean & St. Dev. & Mean & St. Dev. & \\
\hline Panel I: All $(n=93,266)$ & 6846.47 & 6295.38 & 394.32 & 447.82 & 93,266 \\
\hline Placed in a program ( success $=1$ ) & 8846.50 & 8311.24 & 523.64 & 511.54 & 18,464 \\
\hline Not placed in a program (success $=0$ ) & 6352.79 & 5579.74 & 355.10 & 418.81 & 74,802 \\
\hline Placed in a program at a public university $($ public $=1)$ & 7703.71 & 6637.19 & 472.70 & 459.72 & 16,251 \\
\hline Placed in a program at a private university $($ public $=0$ ) & $17,238.51$ & $13,148.84$ & 889.74 & 686.23 & 2213 \\
\hline \multicolumn{6}{|l|}{ Panel II: Placed in a program at a public university } \\
\hline Percentile $\leq 50$ & 6739.55 & 5708.69 & 427.09 & 407.85 & 8170 \\
\hline $75 \geq$ Percentile $>50$ median & 7999.99 & 6896.92 & 520.79 & 487.78 & 3983 \\
\hline Percentile $>75$ & 9337.92 & 7674.83 & 514.15 & 513.76 & 4098 \\
\hline
\end{tabular}

Source: Authors' calculations.

Table 9

The highest and the lowest annual fees in public and private universities (in $2005 \mathrm{TL}$ ).

\begin{tabular}{|c|c|c|c|c|c|c|c|}
\hline Year & & 2000 & 2001 & 2002 & 2003 & 2004 & 2005 \\
\hline \multirow[t]{2}{*}{ Public universities } & Lowest fee & 181 & 209 & 157 & 150 & 148 & 147 \\
\hline & Highest fee & 559 & 781 & 486 & 468 & 461 & 456 \\
\hline \multirow[t]{2}{*}{ Private universities } & Lowest fee & 5103 & 8065 & 5151 & 3779 & 3114 & 4266 \\
\hline & Highest fee & 31,893 & 47,908 & 14,258 & 21,870 & 25,655 & 26,500 \\
\hline
\end{tabular}

Source: Author's calculations based on information from University Entrance Application Booklets, various years, OSYM.

We exclude open university, where the fee was $55 \mathrm{TL}$.

cost of education. Some public university students come from poor families, so they cannot afford to pay tuition. Whether the students' share in financing the cost of higher education can be increased depends on the level of ability and willingness to pay for higher education, assuming that we can deal with the crucial issues of fairness and equal access to quality education by developing a well-functioning system of financial aid. Hence, we look at family income and how much families actually pay for private tutoring and higher education.

In Table 8, Panel I, we show the mean and standard deviation of family income and private tutoring expenditures for various sub-samples. The average tutoring expenditure of those who were placed in a program is substantially higher than that for the ones who were not. ${ }^{15}$ In Panel II, we examine income and private tutoring expenditures of public university entrants according to the percentiles of per-student subsidy they receive. Although public university students are poorer than private university students, those who receive a higher subsidy from the government come from higher income families, again, consistent with our earlier findings. Private tutoring expenditures of students placed in public universities with per-student subsidies in the 50th-75th percentiles are higher than those with per-student subsidies below the 50th percentile. However, above

\footnotetext{
15 Tutoring expenditures are reported as the total spending during the student's high school years, so we divide the total amount by three to find the annual amount. However, based on our own observations, we can say that most of the students attend private tutoring centers only in their senior year in high school, therefore the values reported in the table are probably underestimates of the true annual payments that parents make.
}

the 75th percentile, there is no further increase in tutoring expenditures of students placed in public universities. Our focus in this paper is family income and its effect on university entrance outcomes. We provide information on private tutoring expenditures since this is a plausible channel through which family income might affect university placement.

In Table 9, we present the highest and lowest fees in public and private universities. In public universities, the highest fee is paid only by medical school and state conservatory students. Most schools charge fees in the range 230-330 TL. Comparing the average income of public university students and especially the ones in the top $10 \%$ group to the fees they pay, we can clearly see that the fees are too low. The fees that are paid are lower than private tutoring spending, which is likely to be underestimated. Therefore, clearly there is a gap between the willingness and ability to pay and the actual payment for this group of students. Consistent with this finding, Fig. 1 shows that many public university students have family characteristics that are similar to those of private university students. These findings suggest that public university fees can be increased, at least in the universities with higher per student subsidy.

\section{Conclusions}

In this study, we investigate the university entrance outcomes of students with diverse social and economic backgrounds using nationally representative data from Turkey. We find that the children of families with higher income and education are more likely to succeed in the highly competitive nationwide university entrance exam. 
Students with higher income are more likely to enter private universities than public universities. However, among the students who are placed at public universities, those from families with higher income and more education enter public universities that receive higher per-student subsidies from the government.

With data on per-student subsidy at the program level, we can estimate the subsidy received by each student better than the studies that assume a national or university level average. Our econometric analyses enable us to control for possible selection problems and estimate the marginal effects of socio-economic characteristics on subsidy received for public university entrants as well as for the entire sample.

Our results have important policy implications. When there is tough competition at the university entrance, socio-economic background becomes an important determinant of student success. Private universities can play an important role in providing higher education to students that come from high income families. Among public university students, those from high income families seem to have an advantage in getting into better funded universities. The fact that many of these students have similar socio-economic characteristics with private university students suggests that public university fees can and should be raised. Before a fee raise, policies must be designed to provide financial assistance to students with a poor socio-economic background.

\section{Acknowledgements}

We are grateful to Prof. Giray Berberoglu, Serkan Arikan and Dilara Bakan who used to work at OSYM for providing us with the OSS data and answering our numerous questions. We are grateful to Murside Canturk and Ahmet Kesik at the Ministry of Finance for their help with the education finance data. We benefitted from helpful conversations with Sachi Hatakenaka and Soner Baskaya. We thank Idil Bilgic Alpaslan, Hatice Calgan, Ibrahim Cicekli, Ekrem Cunedioglu, Mert Can Duman, Veli Safak, and Firuzan Topaloglu for their help with organizing the data. The usual disclaimer applies.

\section{Appendix A}

See Table A1.

Table A1

The universities that offer the highest per student subsidy in some majors.

\begin{tabular}{|c|c|c|c|c|c|}
\hline \multicolumn{3}{|c|}{ Major: Economics } & \multicolumn{3}{|c|}{ Major: Computer and Electronics Engineering } \\
\hline 1 & Orta Dogu Teknik & 6922.98 & 1 & Gebze Yuksek Tek Ens & $17,339.01$ \\
\hline 2 & Galatasaray & 5626.66 & 2 & Izmir Yuksek Tek Ens & 12,508 \\
\hline 3 & Bogazici & 5476.78 & 3 & Orta Dogu Teknik & 7884.41 \\
\hline 4 & Hacettepe & 5313.35 & 4 & Hacettepe & 6970.42 \\
\hline 5 & Harran & 4744.37 & 5 & Bogazici & 6469.54 \\
\hline 6 & Ankara & 4361.66 & 6 & İstanbul Teknik & 5765.43 \\
\hline 7 & Yıldız Teknik & 3034.62 & 7 & Ankara & 4470.21 \\
\hline 8 & Dokuz Eylul & 3017.91 & 8 & Dicle & 4241.81 \\
\hline 9 & Ataturk & 2683.53 & 9 & Ege & 3691.38 \\
\hline 10 & Ege & 2622.76 & 10 & Gaziantep & 3535.54 \\
\hline \multicolumn{3}{|c|}{ Major: English Education } & \multicolumn{2}{|c|}{ Major: Dentistry } & \\
\hline 1 & Orta Dogu Teknik & 6945.64 & 1 & Dicle & $14,338.39$ \\
\hline 2 & Hacettepe & 4665.86 & 2 & Hacettepe & $13,445.91$ \\
\hline 3 & Bogazici & 4497.91 & 3 & Gazi & $12,548.09$ \\
\hline 4 & Cukurova & 2446.75 & 4 & Ankara & $11,848.52$ \\
\hline 5 & Ataturk & 2420.62 & 5 & Ataturk & $10,346.75$ \\
\hline 6 & Inonu & 2194.92 & 6 & Ege & 8810.26 \\
\hline 7 & Dicle & 2170.31 & 7 & İstanbul & 8377.06 \\
\hline 8 & Kocaeli & 2123.03 & 8 & Ondokuz Mayıs & 7813.38 \\
\hline 9 & Dokuz Eylul & 2119.95 & 9 & Cumhuriyet & 7640.57 \\
\hline 10 & Uludag & 2087.98 & 10 & Suleyman Demirel & 7244.59 \\
\hline
\end{tabular}

\section{References}

Antoninis, M., \& Tsakloglou, P. (2001). Who benefits from public education in Greece? Evidence and policy implications. Education Economics, 9(2), $197-222$

Atkinson, A., \& Stiglitz, J. (1980). Lectures on public economics. Maidenhead: McGraw-Hill.

Barbaro, S. (2005). Equity and efficiency considerations of public higher education. Lecture notes in economics and mathematical systems (Vol. 557). Berlin Heidelberg: Springer-Verlag.

Behrman, J. (1999). Labor markets in developing countries. In O. Ashenfelter \& D. Card (Eds.), Handbook of labor economics. Amsterdam: NorthHolland.
Caner, A., \& Okten, C. (2010). Risk and career choice: Evidence from Turkey. Economics of Education Review, 29, 1060-1075.

Crean, J. F. (1975, Winter). The income redistributive effects of public spending on higher education. Journal of Human Resources, 10(1), $116-123$.

Dow, W. H., \& Norton, E. C. (2003). Choosing between and interpreting the Heckit and two-part models for corner solutions. Health Services E Outcomes Research Methodology, 4, 5-18.

Ebenstein, A. (2010, Winter). The "Missing Girls" of China and the unintended consequences of the one child policy. Journal of Human Resources, 45(1), 87-115.

Fernandez, R., \& Rogerson, R. (1995). On the political economy of education subsidies. Review of Economic Studies, 62, 249-262. 
Ferreira, F. H. G., Gignoux, J., \& Aran, M. (2010). Measuring inequality of opportunity with imperfect data: The case of Turkey. Policy Research Working Paper 5204, February. The World Bank.

Fields, G. S. (1975, July). Higher education and income distribution in a less developed country. Oxford Economic Papers, New Series, 27(2), 245-259.

Friedman, M. (1962). Capitalism and freedom. Chicago: The University of Chicago Press.

Hansen, W. L., \& Weisbrod, B. A. (1969, Spring). The distribution of costs and direct benefits of public higher education: The case of California. The Journal of Human Resources, 4(2), 176-191.

James, E., \& Benjamin, G. (1987, Autumn). Educational distribution and income redistribution through education in Japan. Journal of Human Resources, 22(4), 469-489.

Lemelin, C. (1992). Short-term redistributive effects of public financing of university education in Quebec. Canadian Public Policy - Analyse de Politiques, 18(2), 176-188.

Leung, S. F., \& Yu, S. (1996). On the choice between sample selection and twopart models. Journal of Econometrics, 72, 197-229.

Liu, J.-T., Chou, S.-Y., \& Liu, J.-L. (2006). Asymmetries in progression in higher education in Taiwan: Parental education and income effects. Economics of Education Review, 25, 647-658.

Pechman, J. A. (1970). The distributional effects of public higher education in California. The Journal of Human Resources, 5, 361-370.

Psacharopoulos, G., Tan, J.-P., \& Jimenez, E. (1986). Financing education in developing countries: An exploration of policy options. Washington, DC: World Bank.

Roemer, J. E. (1998). Equality of opportunity. Cambridge, MA: Harvard University Press.

Rosenzweig, M., \& Schultz, T. P. (1982). Market opportunities, genetic endowments and intrafamily resource distribution: Child survival in rural India. American Economic Review, 72(4), 808-815.
Rozada, M. G., \& Menendez, A. (2002). Public university in Argentina: Subsidizing the rich? Economics of Education Review, 21, 341-351.

Taipei Times. (2000). Ministry sets stage for flexible tuition. January 5 (p. 4). http://www.taipeitimes.com/News/local/archives/2000/01/05/ 0000018358. Accessed 13.02.13.

Tansel, A. (2002). Determinants of school attainment of boys and girls in Turkey: Individual, household and community factors. Economics of Education Review, 21, 455-470.

Tansel, A., \& Bircan, F. (2005, May). Effect of private tutoring on university entrance examination performance in Turkey. IZA Discussion Paper No. 1609.

Tansel, A., \& Bircan, F. (2006). Demand for education in Turkey: A Tobit analysis of private tutoring expenditures. Economics of Education Review, 25, 303-313.

Tuyluoglu, S., \& Albayrak, A. S. (2010). Hayat Pahalılı̆̆ı ve Türkiye'de Illerin Hayat Pahalılığı Sıralamasını Belirleyen En Önemli Faktörlerin Ridge Regresyon Analiziyle Incelenmesi [Cost of living and examining with ridge regression analysis the most important factors that determine cost of living ranking of provinces in Turkey]. The Journal of Faculty of Economics and Administrative Sciences, 15(2), 63-91, Suleyman Demirel University.

YOK (Higher Education Council of Turkey). (2004, November). The current state of higher education in Turkey (Türk Yükseköğretiminin Bugünkü Durumu). Manuscript.

YOK (Higher Education Council of Turkey). (2005, November). The current state of Turkish higher education. Manuscript.

YOK (Higher Education Council of Turkey). (2007a). Report on private universities (Vakıf Üniversiteleri Raporu) (Appendix 6, Table 6).

YOK (Higher Education Council of Turkey). (2007b). Higher education strategy of Turkey (Türkiye'nin Yükseköğretim Stratejisi) (Appendix 16, Table 19). 